\title{
Rat Liver Membrane Preparations
}

Three methods of preparing rat liver plasma membranes were studied to compare the purity, yield, enzyme activity, and ease of preparation. The three methods were:

(1) The method of Neville (1) in which a hypotonic $1 \mathrm{mM} \mathrm{NaHCO}$ solution is used for homogenizing and washing the membranes.

(2) The method of Ray (2) in which Neville's method is modified by the addition of $0.5 \mathrm{mM} \mathrm{CaCl} 2$ to the $1 \mathrm{mM} \mathrm{NaHCO}$ solution and by the use of larger dilution volumes for the homogenization and wash procedure.

(3) A method using $250 \mathrm{~m} M$ sucrose, $0.5 \mathrm{mM} \mathrm{CaCl}$, and $5.0 \mathrm{~m} M$ Tris for the homogenization and washing procedure. The homogenization media is similar to that used by Takeuchi and Terayama (3) but subsequent steps in the procedure differ from their preparation. The large dilution volumes as prescribed by Ray were used in this method.

Methods. Male albino rats which weighed $150-500$ gm were used. The rats were decapitated and the livers were perfused (4) with iced saline solution prior to removal from the animal. Connective tissue was removed and the livers were minced with scissors. Homogenization was done with a loose fitting Dounce homogenizer in volumes prescribed by Neville (1) and Ray (2). In the isotonic sucrose method the dilution volumes of the Ray method were used for homogenization and washing. All homogenates were filtered through four layers of No. 60, No. 80, and No. 120 cheesecloth. For the sucrose gradient purification, centrifugation at $61,000 \mathrm{~g}$ for $2 \mathrm{hr}$ in the Spinco SW 25.1 rotor was used. For the Neville sucrose gradient the modification of Emmelot (5) incorporating a d1.18 sucrose layer between the $\mathrm{d} 1.22$ and $\mathrm{d} 1.16$ sucrose gradient was used.

The final two washes of the purified membranes were made with $\mathrm{H}_{2} \mathrm{O}$ and stored overnight in an ice bath prior to the assays.

The $\left(\mathrm{Na}^{+}, \mathrm{K}^{+}\right)-\mathrm{MgAT}$ Pase was assayed as described by Emmelot et al. (5) at $25^{\circ} \mathrm{C}$ with use of a $60 \mathrm{mM}$ imidizole/glycylglycine buffer, $\mathrm{pH} 7.25$. The inorganic phosphate release was measured by the method of Post and Sen (6). The ADPase and AMPase assays were made similarly by measuring the release of inorganic phosphate. The DNA was assayed by

(C) 1972 by Academic Press, Inc.

All rights of reproduction in any form reserved. 


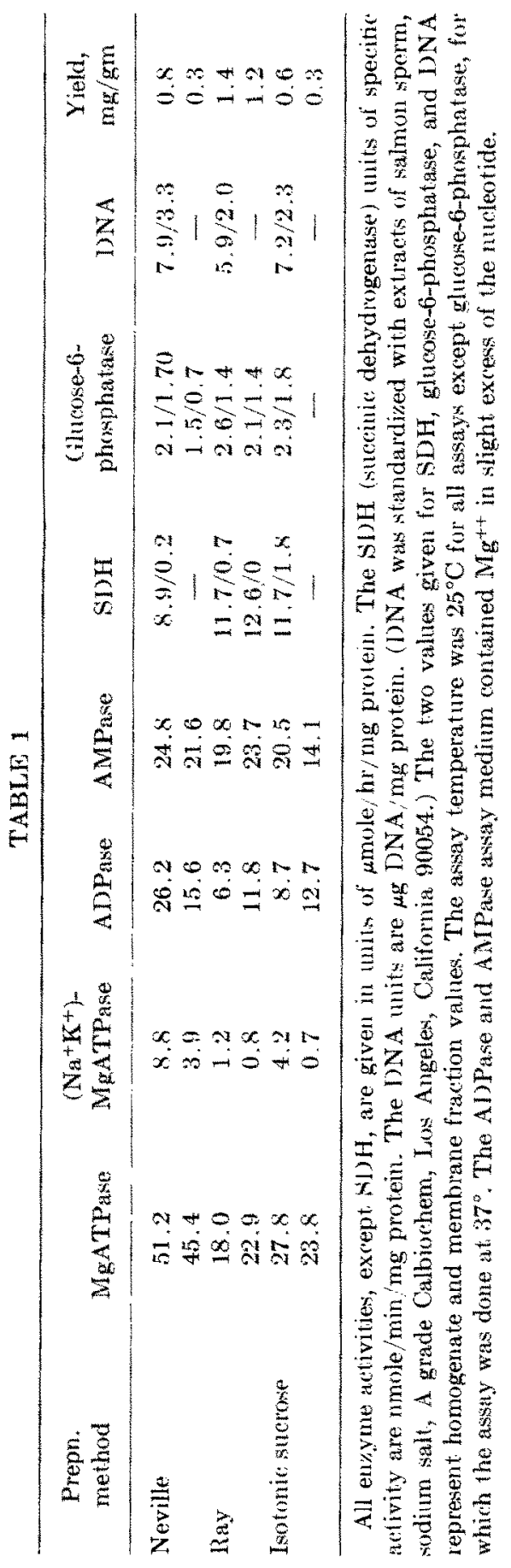


the method of Burton (7). Glucose-6-phosphatase was assayed by the method of Hubscher and West (8) at $37^{\circ}$. Succinic dehydrogenase (SDH) was assayed by the method of Green et al. (9) at $25^{\circ}$. Proteins were estimated by the method of Lowry et al. (10).

Results and Discussion. The results of the study are presented in Table 1. The isotonic sucrose method appears to be the least acceptable method. The mitochondrial contamination is significantly higher while the yield and adenine phosphatase levels are well below those of the Neville preparations. The yield of the Ray preparations is the highest while also giving good mitochondrial separations; however, the adenine phosphatase activities are the lowest of the three preparations. The Neville preparation gave the highest adenine phosphatase activities with an average yield that was $43 \%$ of the Ray preparations.

We confirmed Ray's finding of higher plasma membrane yields when $0.5 \mathrm{mM} \mathrm{Ca}{ }^{++}$and large dilution volumes are used. However, at $25^{\circ} \mathrm{C}$ we did not find the high relative MgATPase specific activities that Ray found at $37^{\circ}$. We found MgATPase, $\left(\mathrm{Na}^{+}, \mathrm{K}^{+}\right)-\mathrm{MgATP}$ ase, and ADPase to be significantly lower in the Ray and isotonic sucrose preparations than in the Neville preparation. A possible inhibitory agent might be the presence of residual $\mathrm{Ca}^{++}$. However, $\mathrm{Ca}^{++}$has been shown to activate ADPase by $250 \%$ over $\mathrm{Mg}^{++}$activation (11). The data in Table 1 shows that ADPase levels are highest in the Neville membranes where no $\mathrm{Ca}^{++}$ was added. The $\mathrm{Ca}^{++}$may hold the membranes together so that less surface area of enzyme is exposed. The fact that AMPase levels remain fairly constant rules out the possibility of an artifact in specific activity due to inclusion of nonenzymic protein in the Ray and isotonic sucrose methods. The consistency of the AMPase levels coincides with the observation of Emmelot and Bos (12) that AMPase is fairly insensitive to a variety of physical and chemical agents.

Summary. The quality of rat liver plasma membranes was examined using three different methods of preparation. Hypotonic $\mathrm{Ca}^{++}$-free preparation media were compared with hypotonic $\mathrm{Ca}^{++}$media and with isotonic $\mathrm{Ca}^{++}$media. The plasma membranes prepared in hypotonic $\mathrm{Ca}^{++}$free media were as pure or better than the other two preparation types, while the $\left(\mathrm{Na}^{+} \mathrm{K}^{+}\right)$-MgATPase, MgATPase, and the ADPase specific activities were higher. The AMPase specific activities were of similar value for all three types of preparation.

\section{ACKNOWLEDGMENT}

This work was supported by grants GM 892 and CA 06734 from the National Institutes of Health, USPHS. 


\section{REFERENCES}

1. Nevilue, D. M., J. Biophys. Biochem. Cytol. 8, 413 (1960).

2. RAY, T. K., Biochim. Biophys. Acta 196, 1 (1970).

3. Takeuchi, M., and H. Terayama, Exp. Cell Res. 40, 32 (1965).

4. Anderson, N. G., Exp. Cell. Res. 8, 91 (1955).

5. Emmelot, P., C. J. Bos, E. L. Benedetti, and P. H. Rumke, Biochim. Biophys. Acta 90, 126 (1964).

6. Post, R. L., AND A. K. Sen, in "Methods in Enzymology" (R. Estabrook and M. Pullman, eds.), Vol. X, pp. 762-768. Academic Press, New York, 1967.

7. Burton, K., Biochem. J. 62, 315 (1956).

8. Hubschen, G., and G. West, Nature 205, 799 (1965).

9. Green, D. E., S. Mil, and P. M. Kahout, J. Biol. Chem. 217, 551 (1955).

10. Lowry, O. H., N. J. Rosebrough, A. L. Farr, and R. J. Randall, J. Biol. Chem. 193, 265 (1951).

11. WattiauX-de Coninck, S., and R. Wattiaux, Biochim. Biophys. Acta 183, 118 (1969).

12. Емmelot, P., And C. J. Bos, Biochim. Biophys. Acta 120, 369 (1966).

Charles F. Hawkins

JOHN A. JACQUEZ

Departments of Physiology and Biostatistics

University of Michigan

Ann Arbor, Michigan 48104

Received January 28, 1972 